Марко М. РАДУЛОВИЋ Институт за књижевност и уметност Београд
Оригинални научни рад

Примљен: 21. 10. 2019.

Прихваћен: 12. 02. 2020.

\title{
ТРИ ПЕСНИЧКА ХОДОЧАШЋА СВЕТОМ САВИ - В. ПОПА, М. ПАВЛОВИЋ И љ. СИМОВИЋ ${ }^{* *}$
}

\begin{abstract}
У раду*** се испитује мотив ходочашћа који се у вези са ликом Светог Саве јавља код Васка Попе, Миодрага Павловића и Љубомира Симовића. Поред тога што се сваки од ових песника током читавог периода стваралаштва на особен начин бавио фигуром првог архиепископа и просветитеља српског, о његовом значају за њихову поезију говори чињеница да су сва три ствараоца поетски ходочастила Савином лику. Наиме, Усправна земль Васка Попе, „Светогорски дани и ноћи” Миодрага Павловића и песма „Ходочашће Светом Сави” Љубомира Симовића тематизују овај мотив. Реч је о покушају успостављања дубље везе са утемељивачем српске духовности што је сведочанство да он у њиховом песништву није само лик, већ и својеврсно поетичко и културолошко опредељење. Како је овај заједнички мотив сваки од три песника реализовао у складу са сопственом поетиком, циљ нашег рада биће да уочимо природу и смисао њихових разлика, али и да истражимо да ли иза њих леже дубље истоветности захваљујући којима можемо да говоримо о Светом Сави као јединственом лику у српској поезији послератног модернизма.

Кључне речи: Свети Сава, Васко Попа, Миодраг Павловић, Љубомир Симовић, ходочашће, поетички и културолошки идентитет.
\end{abstract}

Васко Попа, Миодраг Павловић и Љубомир Симовић враћали су се лику првог српског архиепископа у различитим периодима свог стваралаштва. У поетској (ре)актуелизицији његовог значења и значаја за српску духовност и културу користили су се средњовековним наслеђем и фолклорним предањима, а у складу са својим поетичким оријентацијама, сваки од песника доносио је нов и особен лик Светог Саве, евоцирајући различите епизоде из његовог живота. У песништву ових стваралаца Свети Сава јавља се и као лик

\footnotetext{
*markorad984@gmail.com

** Рад је настао као резултат истраживања у оквиру пројекта Института за књижевност и уметност: Смена поетичких парадигми у српској књижевности 20. века: национални и европски контекст (178016), који финансира Министарство просвете, науке и технолошког развоја Републике Србије.

${ }_{* * *}$ Рад је усмено саопштен у оквиру програма 49. Међународног научног састанка слависта у Вукове дане.
} 
из легенди (Усправна земља В. Попа), младић који пантеистички спознаје истине хришћанства у просторима недирнуте природе („Свети Сава на Атосу”, Љ. Симовић), светац који проговара у тренутку док његове мошти горе на ломачи („Свети Сава на ломачи”, М. Павловић). Једном речју први српски архиепископ чест је мотив у поезији ових песника.

Међутим, о важности фигуре Светог Саве не говоре само појединачне песме, као ни фреквентност са којом се он јавља у њиховом делу, већ чињеница да сва три песника у одређеним тренуцима активирају заједнички мотив у вези са првим српским архиепископом - мотив ходочашћа. То је сигнал да они покушавају да успоставе дубљу везу са утемељивачем српске духовности, те да он у њиховом песништву није само лик, већ и својеврсно опредељење, важно за њихов поетички и културолошки идентитет. Наиме, Усправна земља Васка Попе, „Светогорски дани и ноћи”1 Миодрага Павловића и песма „Ходочашће Светом Сави” Љубомира Симовића тематизују мотив ходочашћења на коме се успоставља дубља веза са фигуром првог српског архиепископа. Овај мотив сваки од ових песника реализовао је у складу са сопственом поетиком. У нашем раду покушаћемо да истражимо да ли иза поетичких особености леже дубље истоветности захваљујући којима можемо да говоримо о Светом Сави као јединственом и целовитом лику у једном току српског послератног модернизма.

Ходочашће представља један од начина успостављања комуникације са прецима: реч је уједно о исказивању пијетета према прошлости и трагању за основама сопственог идентитета. Отуда ходочашће које Попа, Павловић и Симовић подузимају представља њихово одређење према традицији сопствене културе, али и покушај изградње духовног и поетичког идентитета своје песме у садашњости. Другим речима, успостављање односа са Светим Савом и традицијом коју он представља израз је песничке самосвести, односно свести песме о сопственом пореклу.

\section{Ходочашће као пут и као молитва}

Усправна земља Васка Попе обликована је као ходочашће које евоцира судбинске моменте српске историје и духовног идентитета. Дакле, реч је о путовању између преломних тачака историје око којих једна заједница гради своју повест. Свети Сава представља једну од тачака на том путу и стога му је посвећен читав циклус - Савин извор. Међутим, он у Усправној земљи није присутан само у поменутом циклусу, већ представља лајтмотив читаве збирке: присутан у циклусу „Косово Поље”, али и у почетним и завршним циклусима збирке. Наиме, лик Светог Саве већ је наговештен у уводној пе-

\footnotetext{
${ }^{1}$ Књига је објављена као посебно издање: Светогорски дани и ноћи (Павловић 1987) и као циклус у оквиру збирке Кьига старословна (Павловић 1989). За наша разматрања у овом раду питање да ли је реч о књизи или циклусу нема пресудну важност, па се њиме нећемо ни бавити. Сви наводи из Кюиге старословне дати су према Павловић 1989.
} 
сми „Ходочашћа”, а одмах након тога прву станицу путовања представља манастир Хиландар, који су основали Свети Сава и Свети Симеон. У песми „Врачар-поље” из завршног циклуса „Повратак у Београд” песнички субјект откида липов лист и наставља свирку старца-пастира у чијем лику препознајемо Светог Саву. Тако се фигура свеца, односно веза песничког субјекта са њом, јавља као конститутивни елемент збирке Усправна земља.

Због чега је за песничког субјекта Усправне земље тако важна идентификација са Светим Савом? Одговор на то нам даје циклус „Савин извор”. Наслов кореспондира са фолклорним легендама о српском светитељу, али и метафорички упућује на идеју почетка чиме сугерише да је Сава предак од кога у правом смислу речи започиње историја српског народа. Читав циклус организован је као животопис у коме се кроз различите епизоде из светитељевог живота портретише његов лик. Свети Сава је почетак словесности свог народа јер са њим почиње оригинално књижевно изражавање: „Седи на врху крушке / И нешто себи у браду говори // Слуша / Како се медоусто лишће / Његовим речима моли / Гледа / Како по брдима ветар ватроносац / Његовим речима псује." За свој народ Сава такође има пресудну улогу у усвајању и неговању хришћанства, те он код Попе своје вукове храни „књигом господара света”, што представља алузију на Библију, и тако се јавља као културни херој који, поред дара слова, доноси и религиозност. Попа ову чињеницу наглашава тако што деловање Светог Саве обликује као својеврсно крштење народа, односно његово потпуно ослобађање од анималних нагона: „Пере шапе својим вуковима / Да трагови мрачне земље / На њима не преживе.” Песник, при томе, сугерише да на културном и духовном плану делатност Светог Саве не представља раскид са старим словенским наслеђем, већ преображавајући континуитет: „Одвеже вериге сред олује / И земљу од старе храстовине / За стајаће звезде везује."

Попа јасно осећа да је фигура светитеља толико изменила и преобразила националну историју, те да његово деловање у народној свести има вредност потпуно новог почетка. Овакав положај Светог Саве песник ефектно сажима стиховима: „Путује без пута / И пут се за њим рађа.” Дакле, Свети Сава утврђује пут који пре њега није ни постојао и тако у Попиној визији фигура средњовековног светитеља и лика из народних легенди прераста у митског претка од кога заједница почиње да постоји. Другим речима, с деловањем Светог Саве рађа се народна самосвест, што је услов отпочињања историје и приче о њој, односно историјско време почиње заиста да тече тек од Савине појаве, чиме се он показује као ванвремен:

Лево од њега тече време

Десно од њега тече време

Он корача по сувом

У пратњи својих вукова

У Попиној поетској визији Свети Сава не ходи, дакле, кроз време него изнад и изван њега. Ослобођен временског тока, он гради пут којим се из 
историје избавља, чиме уједно постаје и ванвременски симбол културе којој припада.

Управо због тога идентификација са светим претком од кључног је значаја за конституисање поетичког и духовног идентитета Попиног песничког субјекта. Тај процес можемо пратити, како смо већ наговестили, од самог почетка збирке. У песми „Ходочашћа” истиче се разлог поласка на пут: реч је о трагању за сопственим идентитетом и суштином: „Ходам са очевим штапом у руци / Са упаљеним срцем на штапу / Стопала ми сричу слова / Која ми свети пут исписује”. Задатак ходочасника је да одгонетне тај „свети пут” тако што ће га прећи и тиме рекреирати. На почетку ходочашћа путник може само да слути значење и значај пута. Међутим, у том почетном наслућивању, стиховима „за сада ми на вучје сазвежђе личе”, ходочаснику као да се одмах указује лик Светог Саве. Наиме, ови стихови наговештавају фигуру „вучјег пастира", која у Попиној поезији, у складу са његовом инспирацијом фолклорним наслеђем, управо представља Светог Саву.

Напуштање профаности, боравак у просторима сакралности и повратак у свет ради ширења искуства стеченог у одсуству, заједничке су тачке у песничким биографијама Попиног Светог Саве и његовог ходочасника. О томе сведоче стихови којима се на различитим местима Усправне земље оцртава песничко ја, као и они који се односе на лик српског светитеља из песме „Живот Светог Саве”.

Уводни стихови „Живота Светог Саве” гласе:

Гладан и жедан светости

Напустио је земљу

И своје и себе

Док су, након описивања искуства стеченог избивањем, завршни стихови у знаку повратка:

Узјахао је штап

Вратио се на земљу

И ту нашао и своје и себе

Уводна строфа песме приказује типичан почетак пута подвижника-аскете, али бајковито стилизован. Одвајање од породице и бескомпромисна тежња ка светости представљају један од високих захтева хришћанске вере. У хагиографској литератури новозаветне речи често су коришћене као мотивација светитељевог опредељења за живот у служби Богу. Савин хагиограф Доментијан управо је Христовим речима: „Ко љуби оца или матер више него мене, није мене достојан; ко не узме крста свога и не иде за мном, није мене достојан" (Доментијан 1970) мотивисао Растков одлазак на Свету Гору. Завршна строфа Попине песме сугерише да након избивања, Свети Сава постаје пастир српског народа што одговара његовој историјској улози.

Када упоредимо стихове којима се описује лирско ја Усправне земље, видећемо да оно у великој мери понавља назначени пут Светог Саве: „Приспео сам с пута / Прашњав и гладан / И жељан другачијег света” („Хилан- 
дар”) стихови су којима се (само)одређује песнички субјект на првој станици ходочашћа. Завршетак збирке и смисао подузетог ходочашћа описују стихови из песме „Повратак у Београд”:

Вратио сам се с пута

Да сазрело камење из завежљаја

Овде на тргу разделим.

Они су у знаку повратка чиме указују да Попин ходочасник након избивања из света профаности и боравка у просторима сакралности, постаје стваралац-проповедник по узору на светог претка. Овако оцртан идентитет лирског ја додатно је проширен чињеницом да он наставља свирку старцапастира са Врачар-поља: „Откинуо сам липов лист / И свирку ти продужио”. Дакле, успостављање везе са духовним претком има самоодређујући значај за модерног песника. Попин ходочасник тако описује исти лук којим је и Свети Сава прошао у песми „Живот Светог Саве”. Оба јунака своје путовање започињу жеђу за светошћу, жудњом за другачијим светом, напуштањем профаног простора, „себе и својих”, а завршавају у поновном налажењу сопства и других, те у дељењу дарова стечених избивањем.

У овом тренутку потребно је да упоредимо Попиног и Павловићевог Светог Саву из „Светогорских дана и ноћи”. Као и Попин лирски јунак, тако и Павловићев песнички субјект посећује Свету Гору. Међутим, међу њима постоји једна важна разлика: Попин глас себе отворено назива ходочасником и тако одмах на почетку одређује природу свог путовања, док код Павловића такво одређење изостаје.

Видели смо да песнички субјект Васка Попе од самог тренутка зна који је циљ његовог путовања. Сигуран је, при томе, и које ће стопе на том путу пратити, оне су истовремено важне за њега као индивидуу, али и за заједницу којој припада. Управо ту лежи разлог богатих културолошких слојева и поетичког приступа историји у Усправној земљи. Није само реч о индивидуалном подвигу, већ и о покушају песничког осмишљавања историјског искуства заједнице. Отуда је Попин Хиландар, као и други манастири који се помињу у Усправној земљьи, истовремено духовни, али и културолошки и историјски симбол. Такав је, видели смо, и његов Свети Сава.

За разлику од Попе, Павловићев доживљај Свете Горе индивидуалнији je. Атос је за овог песника пре свега живо место вековима старе мистике. Ово је разлог што код Павловића изостаје шире евоцирање културолошких слојева. Уместо њих долази до судара профаности и светости, поетског и сакралног, а читава збирка обликује се као духовни оглед песничког субјекта. Међутим, управо се по том индивидуалном опиту Павловић приближава оном слоју светогорске баштине који често остаје непримећен иза свести о томе шта та баштина значи у културолошком и историјском смислу - подвижничком искуству. Другим речима, песнички субјект „Светогорских дана и ноћи" покушава да ступи у додир са духовним искуством монаха који се подвизавају у пештерама. Отуда он своју песму не гради ослањајући се на богату симболику и културолошки потенцијал светогорских манастира, већ 
је његово лирско ја често на путу између манастира, у просторима дивље и тајанствене природе Атоса, а његови стихови подсећају на мистичке контемплације у којима се глас модерног песника укршта са профетским искуством православне духовности. ${ }^{2}$ Иако одређиван као песник културе, Павловић је заправо стваралац кога највише интересује оно до чега кодификаторска културолошка свест тешко досеже: неухватљива духовна енергија положена иза културних симбола. Управо зато су многе Павловићеве песме из „Светогорских дана и ноћи" језички и рефлексивни опити који се приближавају оном току средњовековља и светогорског наслеђа који у модерној култури није реципиран толико колико други видови тог наслеђа - православној мистици.

Међутим, упркос истакнутим разликама, Павловића са Попом спаја фигура Светог Саве. На крају духовне авантуре по Светој Гори, путнику се указује светац који се све време слути. За разлику од Усправне земље, где је Свети Сава присутан као лик и као мотив, са којим се успоставља веза, у „Светогорским данима и ноћима” његово присуство изостаје све до завршне песме, иако се све време наслућује. Павловићевом песничком субјекту светац се директно обраћа са јасном поруком: да се врати у свој простор и тамо шири искуство које је стекао на поклоничком путу:

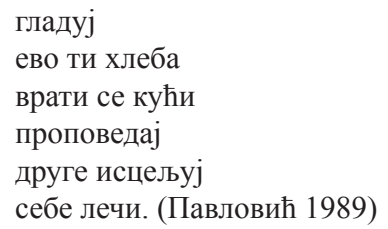

Савино обраћање реализује се као завет који ваља испунити. Тако индивидуално наслућивање светости, кулминира у путниковој визији Светог Саве. Управо због тога, на самом крају књиге, Павловићев путник прераста у ходочасника, а, кроз налог свеца, његове индивидуалне духовне контемплације добијају шири смисао - песник је дужан да их подели са другима. Отуда се искуство боравка на Светој Гори, односно сусрет са Светим Савом, за Павловићеву поетику чини као битно и одређујуће. Овакав завршетак „Светогорских дана и ноћи” приближава Попу и Павловића, чиме се њихов однос према српском светитељу показује као комплементаран. Оба песника (ауто)поетички одређују своје стваралаштво тако што своју песму доводе у везу са наслеђем које је утемељитељ српске књижевности и духовности оставио. На тај начин, Попа и Павловић транспонују у модерно песничко искуство оно што се назива светосавски завет, сведочећи да је модерна српска песма у једном свом току и светосавска: посвећена стваралачком рекреирању

\footnotetext{
${ }^{2}$ Реч је о духовном брзопису „унутрашњих доживљаја модерног ствараоца у сусрету са древном сакралном енергијом. Одломци су углавном ненасловљени, готово да нема историјских реминисценција, а у потпуности изостаје историјска нарација, присутна у другим Павловићевим збиркама” (Радуловић 2017: 174).
} 
културних, историјских и мистичких потенцијала који се налазе у фигури српског светитеља.

Попином и Павловићевом ходочашћењу придружује се Љубомир Симовић песмом речитог наслова „Ходочашће Светом Сави”. Међутим, код Попе и Павловића ходочашће је, уз све културолошке импликације, индивидуални подвиг, о чему сведочи чињеница да се песнички субјект оглашава из првог лица једнине. У Симовићевој песми на делу је обраћање заједнице из првог лица множине уз инвокацију светитеља. Осим тога изостаје мотив физичког путовања, присутан код Попе и Павловића, па се ходочашће о коме је у наслову реч, пре свега одвија као молитва, односно духовно ходочашће речима. Није у питању молитва која се изговара у самоћи, већ она која се приноси на служби. Поред „ми” перспективе и инвокације светитеља, Симовићева песма одликује се и другим структуралним сличностима са молитвом: у њој је присутан топос самоунижења, као и молба свецу за избављењем из тешке ситуације. Осим ових формалних блискости, „Ходочашће Светом Сави” директно подсећа и на средњовековне молитве упућиване овом светитељу. Наиме, као некада у тешким временима, тако и у модерном добу заједница моли свеца за спас из ситуације у којој је егзистенцијално угрожена. Симовић у беседи ${ }^{3}$ поводом уручења Жичке хрисовуље цитира једну од ових молитви и констатује да се ситуација ни након неколико векова није значајно променила за заједницу чији је утемељитељ Свети Сава: „С обзиром на околности у којима смо се нашли, за нашу молитву бисмо могли позајмити речи из молитве којом се негде око 1241. године неки непознати калуђер из Милешеве обратио Светом Сави: 'Пожури се, Саво Свети, и пакости избави нас, јер јади велики и ратни рабе твоје обузимају'... Очито је да бисмо ми данас пред наше свеце могли изаћи са истим оним жалбама и молитвама са којим су пред њих излазили наши несрећни преци пре седам или осам стотина година, што значи да се несрећне околности за нас ни током толиких стотина нису промениле. Међутим, ако се нису промениле те околности, променили смо се ми.” Симовић у свом исказу инсистира на две ствари: суштински непромењеним спољним околностима, али и промени која је захватила заједницу. Управо се у његовој песми истовремено описују мрак савременог доба, али и одступање заједнице од светосавских вредности.

Песма је подељена на пет делова. У прва три даје се ефектан опис времена у коме се народ који упућује молитву обрео. Кроз опонирање светог и профаног, Симовић не само да описује тренутно стање него прецизно утврђује колико је оно удаљено од пута који је утврдио Свети Сава. Све недаће проистичу из чињенице да је свет остао без своје сакралне основе, односно да је веза са почетком изгубљена: „Ево у каквом мраку остаје свет / кад се угаси света ватра." Реч је о времену у коме је угрожен опстанак свих вредности које су вековима стваране. Осим што угроженост долази споља, она је још већим делом унутрашња - заједница сама одустаје од сопствених идеала.

${ }^{3}$ https://otacmilic.com/ljubomir-simovic-molimo-se-da-progledamo/ Последњи пут приступљено: 2.10. 2019. 
Иако је историјска ситуација средњовековних предака и савременика слична, у знаку угрожености, њихово духовно стање суштински се разликује. Управо је због тога егзистенцијални усуд савременика безнадежнији: они су у опасности да изгубе сопствени идентитет. Прекид континуитета са прецима, за савременике може значити само једно - онемогућавање везе са потомцима: „Из овог мрака / глас нам не допире / ни до праоца, / ни до праунука!” Дакле, губљење везе са прошлошћу, није ништа друго него угрожавање сопствене будућности.

Историјски мрак из кога се заједница обраћа представља непријатељски настројен свет према вредностима које је управо Свети Сава утемељио: „,У овом мраку стављају на муке / и секу оног који браћу мири.” То је време у коме царују трговци, а не ствараоци, време које се одрекло трагичних али и искупљујућих тренутака сопствене историје: „Из овог мрака, што труне и трује, / не чује се позив ослободиоца. / Одакле ће се чути, ако се не чује / са крста, с точка, с Косова и с коца?” Свети Сава се тако показује као нераскидиво повезан са историјом свог народа, посебно са њеним трагичким искуством. Због тога је Симовићев Сава близак оном из Усправне земље: и у једном и у другом случају српски светитељ јавља се као заштитник заједнице у најтежим тренуцима њеног историјског трајања.

У четвртом делу „Ходочашћа Светом Сави”, светитељ се директно моли за помоћ. Симовић ту прибегава парадоксима које је и средњовековна химнографија користила приликом грађења лика Светог Саве. На трагу Теодосијеве службе Светом Сави ${ }^{4}$ модерни песник парадоксално приказује Саву као сина који је духовно родио свога оца: „сине, који си подигао оца, / оче, чији пепео синови расуше!” Средњовековну слику савремени песник ефектно надопуњује каснијим догађајима, поетски алудирајући на спаљене мошти Светог Саве, њихову ујединитељску улогу, али и немаран однос потомака према њима.

У петом и завршном делу Симовић додатно обликује Савин лик. Песник истиче универзални хришћански значај његове појаве: Чашо вина, / хлебе, / свето слово”; „уље маслиново / које нас храниш и које нам сијаш”; „Лађо с које се види Јерусалим". Проширује хришћанске симболе егзистенцијалним значењем: „Путе којим се враћа блудни син, // ратник из рата, // с робије робијаш!”. Такође, фигуру Светог Саве конкретизује локалним симболима, речитим за заједницу којој припада: „шљиво крај извора”. Реч је о типичном Симовићевом поступку којим овај песник својим симболима истовремено подарује универзалне вредности, али и конкретност и живописност реалног искуства.

Песник завршава обраћање светитељу употребом парадокса што песму чини изузетно ефектном:

Чуј нас, свети оче, који одјекујеш / од звона и клепала који траже спаса! Кад ћеш нас чути, ако нас не чујеш / данас, кад немамо ни језика, ни гласа?

\footnotetext{
4 „Телесно родитељство / и духовно синовство повинув, / свом сину младићу у старости / послушан у пустињи, Симеоне, јавио си се” (Теодосије 1988: 45).
} 
Помоћ светитеља неопходна је у судбинском тренутку када заједница која му се обраћа остаје управо без оних атрибута које јој је он симболично донео: сопственог језика и гласа. Када је заједница измењена до непрепознатљивости, изгубивши вредности које је кроз историју баштинила, једино што јој преостаје јесте да упути молитву свом духовном оцу. Отуда се у Симовићевом песништву Свети Сава, као и код Попе и Павловића, јавља као утемељитељ и заштитник заједнице, односно доноситељ највиших духовних вредности: културе и религиозности. Свети Сава је истовремено помоћник, али и идеал у односу на који се заједница самерава.

Као код Попе и Павловића, тако је и у Симовићевој песми Свети Сава неко ко борави у посебном простору сакралности, али у вези са светом у коме обитавају његови потомци коме они прибегавају у тешким тренуцима као спасу од реалности у којој су се затекли, односно коју су сами створили. Ипак, однос песничког субјекта Симовићеве поезије и Светог Саве посреднији је него код Попе и Павловића. За разлику од њих код Симовића нема директног контакта са светитељем, а раздаљине које су успостављене могуће је прећи само молитвеним обраћањем. Управо због тога у његовој песми први српски архиепископ јавља се као светац заштитник и духовно-морални узор заједнице коме се она обраћа искључиво бираним речима заједничке молитве. Тако је код Љубомира Симовића осим аутопоетичког значаја Савиног лика, изнад свега потенцирана његова културно-историјска и етичка улога.

\section{Свети Сава као културни, поетски и духовни симбол}

Српска поезија друге половине двадесетог века донела је слике апокалиптичне историјске реалности у којој су угрожене темељне духовне вредности као што су сећање и континуитет са прошлошћу. Упоредо са овим сликама јавља се и простор сакралног - он се открива, за њега се бори, њему се обраћа за помоћ, од њега се неретко и удаљава. На тај начин, апокалипса и сакралност представљају два пола стваралаштва послератног модернизма. У складу са својим поетикама Попа, Павловић и Симовић трагали су за просторима сакралности на различитим местима и традицијима. Међутим, као заједничко у тим трагањима издваја се то што су сва три песника, просторе сакралности налазили у културним и религиозним симболима српског средњег века, а посебно у лику Светог Саве, коме су посветили неке од својих најуспелијих песама.

Сваки од ових стваралаца на свој начин актуелизовао је појаву и значај Светог Саве. У Усправној земљи он је присутан пре свега као митски архетип и културни херој. У његовом лику Попа је поетски укрстио фолклорно-митолошко и средњовековно-хришћанско значење. У складу са основним мотивом збирке - ходочашћем, Попа потенцира изнад свега културотворни и историсофски значај фигуре Светог Саве. Иако је реч о епском захвату и настојању да се песнички осмисли и артикулише историјско искуство, Попин 
ходочасник проговара из ,ја" позиције и у извесној мери је индивидуализован, па у њему можемо препознати фигуру песника који постаје проповедник по узору на светог претка. У томе је Попа близак са Павловићем, чије је песничко путовање по Светој Гори у великој мери индивидуални подвиг, обележен контемплацијом о природи светости, стварања и ништавила, који се на свом крају ипак показује као ходочашће, кроз завет добијен од Светог Саве: да се искуство стечено у светом простору транспонује у световни простор из кога песник долази и у који мора да се врати. Симовић, пак, у лику светитеља види највише духовне и етичке идеале на којима је заједница изграђена. Отуда фигура песника изостаје, а обраћање Сави упућује се у име заједнице као молитва којом се покушава поновно успостављање прекинуте везе између Светог Саве и његових потомака.

Иако сваки од ових стваралаца обликује лик Светог Саве у складу са сопственим поетичким вредностима и сензибилитетом, међу њима постоје значајне сличности на основу којих можемо да говоримо о Светом Сави као јединственом лику. Он се код сва три песника јавља као утемељитељ заједнице, њен заштитник у свим временима, опониран профаном добу и декаденцији коју историјски ток носи са собом. Изнад свега, Свети Сава нераскидиво је везан са историјским искуством свога народа, а духовни потенцијал његовог лика представља тачку (по)етичког самоодређења модерне српске поезије. Управо међусобна блискост ова три песника која простиче из њихове особите везе са Светим Савом представља речито сведочанство о присутности и актуелности светосавског наслеђа и у 20. веку.

\section{ЛИТЕРАТУРА}

Извори

Павловић 1989: М. Павловић, Кьига старословна, Београд: СКЗ.

Попа 1997: В. Попа, Песме, Београд: Народна књига-Алфа.

Симовић 1990: Љ. Симовић, Горњи град, Београд: БИГЗ.

\section{Секундарна}

Доментијан 1970: Доментијан, „Живот светога Саве”, у: Стара српска књижевност I, Нови Сад: Матица српска, Београд: СКЗ.

Попа 2008: В. Попа, Јутро мислено: немањићско доба, зборник средюовековне српске поезије, Нови Сад: Академска књига.

Радуловић 2017: М. М. Радуловић, Српсковизантијско наслеђе у српском послератном модернизму (Васко Попа, Миодраг Павловић, Љубомир Симовић, Иван В. Лалић), Београд: Институт за књижевност и уметност.

Теодосије 1988: Теодосије, Службе, канони и Похвала, Београд: Просвета, СК3. 
Marko M. Radulović

THREE POETIC PILGRIMAGES TO ST. SAVA

- V. POPA, M. PAVLOVIĆ AND LJ. SIMOVIĆ -

(Summary)

The paper analyses the motif of pilgrimage to St. Sava appearing in the Earth Erected by Vasko Popa, "The Days and Nights at Mount Athos" by Miodrag Pavlović and the poem "Pilgrimage to St. Sava" by Ljubomir Simović. We have established that each of these poets is trying to create a deeper bond with the forefather of Serbian spirituality, which is why in their poetry, he is not merely a character, but a particular commitment, important for their poetic and cultural identity.

Even though each of these creators shapes the character of St. Sava according to their own poetic values and sensibility, they also show significant similarities due to which we can talk about St. Sava as a unique character. All three poets see him as a forefather of the community, its eternal protector, opposed to the profane age and decadence characteristic of modern times. Above all, St. Sava has an inextricable bond with the historical experience of his people, while the spiritual potential of his character represents a point of poetic self-determination of contemporary Serbian poetry. The closeness between these three poets, which arises precisely out of their particular connection with St. Sava, is an articulate testimony of the presence and importance of St. Sava's heritage in the $20^{\text {th }}$ century as well. 